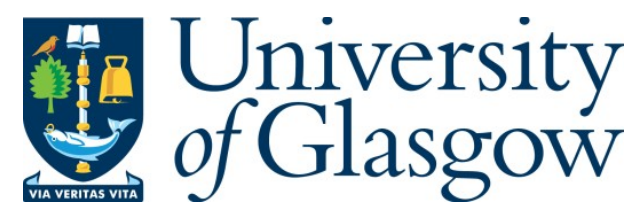

Davis, J. B. and McMaster, R. (2020) A road not taken? A brief history of care in economic thought. European Journal of the History of Economic Thought, 27(2), pp. 209-229.

(doi: $\underline{10.1080 / 09672567.2020 .1720767)}$

This is the Author Accepted Manuscript.

There may be differences between this version and the published version. You are advised to consult the publisher's version if you wish to cite from it.

https://eprints.gla.ac.uk/199207/

Deposited on: 8 October 2019

Enlighten - Research publications by members of the University of Glasgow http://eprints.gla.ac.uk 


\title{
A road not taken? A brief history of care in economic thought ${ }^{1}$
}

\author{
John B Davis* and Robert McMaster** \\ *Amsterdam School of Economics, University of Amsterdam, PO Box 15867, $1001 \mathrm{NJ}$ \\ Amsterdam, and Department of Economics, Marquette University, PO Box 1881, Milwaukee, \\ WI 53201-1881 \\ E-mail: john.davis@marquette.edu \\ ${ }^{* *}$ Adam Smith Business School, University of Glasgow, University Avenue, Glasgow G12 \\ $8 Q Q$. \\ E-mail: robert.mcmaster@glasgow.ac.uk
}

\begin{abstract}
Care is central to the human experience and part of the social provisioning process. Adam Smith recognized this, associating care with sympathy. Later contributions in the political economy tradition also provide scope for an analysis of care, but none as developed as Smith's. With the emergence of the current mainstream, care is marginalized. Kenneth Boulding's analysis provides an opportunity to interrogate care in the economy, but he fails to explicitly acknowledge care. It is left to feminist economics to highlight the centrality of care. An implication is that it challenges the conventional rubric of economic organization predicated on self-interest.
\end{abstract}

Keywords: care; Smith; feminist economics; Boulding; social provisioning

JEL Classification: B10; B54; 100; Z00

\section{Introduction}

The literature on care frequently refers to the broad definition provided by Bernice Fisher and Joan Tronto in 1990:

"On the most general level, we suggest that caring be viewed as a species activity that includes everything that we do to maintain, continue, and repair our 'world' so that we can live in it as well as possible. That world includes our bodies, our selves, and our

\footnotetext{
1 We wish to acknowledge the highly insightful guidance and friendly criticisms of the editors and three reviewers of this journal. We have no doubts that they greatly improved the paper's analysis and argument. We are also grateful the participants at a session of the 2019 Japanese Society of the History of Economic Thought conference at Fukuoka University. Finally, we acknowledge the financial support of the Scottish Economic Society, which enabled the authors to progress with the writing of the paper. Of course, the standard disclaimer applies.
} 
environment, all of which we seek to interweave in a complex life-sustaining web" (Fisher and Tronto, 1990: 40; Tronto, 1993: 103; Tronto, 2013: 19, original emphasis).

Accordingly, care is a complex and multi-dimensional concept. In subsequent works, Tronto $(1993,2013,2017)$ defends the breadth of the definition, arguing that it provides an overarching frame within which specific forms of care may be nested. In short, care is essential to the functioning of society and our being-in-the-world (Engster, 2005). Attentive interest, concern, as well as subsequent activities and actions following such attention are all manifestations of care and caring. For much of the literature, care is profoundly relational (Himmelweit, 2007; Tronto, 2013). It has psychological (through emotional attachments and motivations), labor (through the functional delivery of care activities), and philosophical (through ethical considerations) properties (Engster, 2005; Tronto, 2013). Our purpose in this respect, is to explore how the concept of care as an aspect of social provisioing emerged and then virtually disappeared in economics.

In this paper, we trace and analyze the disparate and fragmented economic approaches to care. 'Approaches' may be endowing too much in the way of acknowledgment, as we believe that economists of all sorts - with the exception of feminist contributions - have either overlooked or failed to appreciate the centrality of care to human existence. As Julie Nelson (2016: 12) argues, "The place of care in the economy is everywhere." Moreover, Virginia Held (2006: 3 ) observes, "It [care] has the potential of being based on the truly universal experience of care. Every human being has been cared for as a child or would not be alive."

Perhaps as a consequence of the mechanical modelling associated with mainstream economics (Nelson, 2006), at best, care is marginalized in economic thinking (Folbre, 1995). This makes tracing a history of care in economic thought challenging. Nonetheless, to varying degrees it is possible to locate a recognition of the conditions of care in the works of Adam Smith, Karl Marx, and Thorstein Veblen. Thereafter, however, the trail becomes increasingly faint, reflecting, we venture the change in core and periphery elements in economics following the emergence and subsequent domination of thinking shaped by the utility maximizing atomistic individual. In other words, the "social provisioning" (Power, 2004) approach of political economy gave way to the scarcity, choice, and the optimization rubric of neoclassicism and modern mainstream economics.

There is much discussion in the care literature that care presents a contrasting ethical orientation to Kantian deontology, and consequentialism and utilitarianism (for example, Edwards, 2009; Engster, 2005; Gilligan, 1982; Griffiths, 2008; Held, 2006; Noddings, 1984; Tronto, 2013). Held (2006: 10) describes a care ethics as, "the compelling moral salience of attending to and meeting the needs of the particular others for whom we take responsibility." Importantly, for Held, and in sharp contrast to deontology and consequentialism, an ethics of care, "values emotion rather than rejects it" (Ibid.). Emotions, such as sympathy, empathy, responsiveness, and sensitivity are viewed as central to an authentic caring. This position aligns with a lineage in economic thinking from Adam Smith's Theory of Moral Sentiments (TMS) (Ballet, et al, 2018; Terjesen, 2011) to Nancy Folbre's (1995) noted "Holding hands at midnight" article and beyond.

In our view, outlining a history of care in economic thought illuminates the possibility of a platform for the development of a coherent conceptualization of care in economics. We consider this a matter of some importance given that care theorists and some economists primarily feminist economists - argue that a caring approach would yield a different configuration of economic institutions (Folbre, 1995; Nelson, 2006; Tronto, 2013; 2017). It also reveals the inherent problems for some types of economics to take care seriously (Ballet, et al, 2018; Davis and McMaster, 2017). 
In section 2, we outline the principal aspects of the feminist economics approach to care, in particular, caring labor. Feminist economics, we venture engages with the three dimensions of care: ethical, labor, and psychological. In doing so, feminist economics re-energizes the notion of social provisioning evident in earlier political economy and other approaches. Section 3 discusses care in pre-neoclassical economic thought; specifically, the approaches of Smith, Marx, and Veblen. To the best of our knowledge, other prominent figures in the history of economics, such as Keynes, were not overly preoccupied with developing a conception of care, given its perceived lack of relevance to the focus of their work. The following section turns to Kenneth Boulding's systems analysis. We find that Boulding's work provides important foundations for the interrogation of care, but we argue that he fails to develop an explicit narrative on care. Section 5 considers care in mainstream economics. Employing health economics as an illustrative case, we argue, at best care is marginalized in the mainstream. Caring is subject to the whims of egocentric utility maximizers. The next section returns to discussing feminist economics addresses the mainstream marginalization of care, reinforces the responsibility to care, and recent attempts to place care at the center of economic analysis. Section 7 concludes.

For us, feminist economics' endorsement of social provisioning provides an important affinity with (Classical) political economy and Kenneth Boulding. Feminist economists, such as, Nancy Folbre (1995), Julie Nelson (2006), and Susan Himmelweit (1995, 2007) also explicitly embrace the work of prominent thinkers in the care literature, such as Carol Gilligan (1982), Virginia Held (2006), Joan Tronto (1993), and Kari Waerness (1984). In our view, these features furnish feminist economics with the capacity to overcome much of the shortfall of the mainstream literature in this area.

\section{Feminist economics: Caring labor and gender}

In economic thinking, feminist economics has been, and remains the most significant source of advancing the importance of care in the economy and economic behavior. In particular, feminist economists argue that the shape of mainstream economic thinking marginalizes care through its separation of the economy from society. Tronto (2013), for instance, argues that Western thinking is infused by the difference between the polis and oikos (public and private) in Ancient Greek philosophy. The former concerns politics and power, and the latter comfort and care. The Cartesian dual between mind and body further reinforces this binary. Similarly, Nelson (2003) alludes to the historical precedent provided by the Victorian model of the family with male breadwinner and female homemaker. The domain of care is confined to the home and is feminized. These approaches contribute to the visualization of the economy as machine; the site of reason and knowledge, markets, self-interest, and so forth, and therefore delineated as masculine. By contrast, the home is characterized as non-economic (i.e. nonmarket) and by virtue, emotion, care and compassion, and such like (Nelson, 2003; 2011). Given the mechanical underpinnings of the neoclassical approach, the prospect of care constituting its focal point are accordingly not promising. Thus, feminist economics investigates and challenges this cleavage between economy and society, in general, and in analyzing care, in particular. Feminist economists especially question the adequacy of standard economic practice and method (for example, Folbre, 1986, 1995; Nelson, 2003). One particular issue identified is the value-ladeness and partiality of the conventional approach. Economics is heavily gendered in its alleged objectivity, preference for quantification, abstraction, rivalry, logical consistency, absence of emotion, rigor, and hardness - properties associated with masculinity. By contrast, subjectivity, qualitative approaches, co-operation, emotion, and intuition are associated with femininity, and are characteristics that are usually considered inferior to masculine ones (for example, Bergmann, 1986; Nelson, 1995; 2006; 2016; van Staveren, 2001). At the center of this difference is the selfish, disconnected, optimizing Homo economicus. Feminists argue that this is an utterly 
inadequate account of both male and female behavior. In developing our argument, we acknowledge there are multiple threads in feminist thinking on care, although as we understand it, much of the feminist economic literature centers on the labor dimension of caring. Nonetheless, it is not possible in the space available to provide a comprehensive discussion. Instead, what follows, we believe is illustrative of feminist thinking in the area.

Marilyn Power (2004) compellingly argues that feminist economics' analytical entry point is "social provisioning", which she describes as social processes that emphasize the interdependence of individuals in organizing to address their needs, wants and to socially reproduce ${ }^{2}$. For present purposes, Power emphasizes caring labor and acknowledges its ethical properties as integral to social provisioning. To a large extent this reflects the feminist literature. While there is unequivocal acknowledgement of the psychological and philosophical as properties of care, much of the literature situates them in the context of caring labor (for example, England, et al, 2002; Nelson, 2011; van Staveren, 2001; 2005; Wagman and Folbre, 1996). From this, two prominent themes emerge: the undervaluation of caring labor and relatedly, the disparities between female and male wages.

Considering the first theme, the origins of the undervaluation of caring labor lies in the location of the domain of care as non-economic (the home), and hence not priced in the marketplace (van Staveren, 2001). This oversight became increasingly apparent when women's labor force participation rates began to rise in the 1970s (especially in developed economies). National income accounting methods then recorded income increases based on the replacement of women's unpaid labor in the household by paid labor in the market (both from women's market employment and from market replacement of formerly unpaid home labor services), though essentially all that had happened was that the form of labor was different. This made it clear that previously unaccounted, unpaid labor outside the market was valuable, leading to the conclusion that national income accounting required that unpaid labor should somehow be included (for example, Himmelweit, 1995; Ironmonger, 1996; Wagman and Folbre, 1996). Though there were different ways in which this accounting could be done, all of them involved placing a market value on the labor that went unpaid in non-market household activity. This meant the ultimate arbiter of the value of unpaid labor was the market, and it also held the further implication that unpaid labor had no value unless it could be measured in market terms. This led to the question whether the market was an appropriate means of evaluating unpaid labor.

Another tranche of the literature challenges the levels of remuneration associated with care work (for example, England, et al, 2002; Folbre and Nelson, 2000). In particular, the argument that caring labor involves some form of intrinsic satisfaction implies that there is a certain motivational orientation in care work that may be undermined by higher wage levels. In other words, there is a binary between "love and money" (Folbre and Nelson, 2000). By appealing to extrinsic motivation in the form of monetary incentives, the intrinsic rewards of caring are undermined. Essentially, this is a variation of Richard Titmuss' (1971) classic comparative

\footnotetext{
2 Power identifies five components to what she views as a common methodology in Feminist economics: (1) caring and unpaid labor as "fundamental"; (2) the application of well-being as a measure of economic success, and intrinsic to interrogating economic reality are: (3) power relations in economic, political and social processes; (4) ethical goals and values, (5) differences in race, class, gender, and other group characteristics. Power (2004: 7) observes that the concept of social provisioning is "classical" rather than "neoclassical" in origin. We agree in that neoclassicism (nor the current mainstream) does not incorporate (1), (3), (4), or (5) in its analysis. In our view, standard economics embraces a form of (2) founded on utilitarianism.
} 
study of blood donation in the US and UK. Money rewards for donations in the US led to deteriorations the quality of blood supplied and undermined the civic virtues associated with the practice as gift giving. By contrast, feminist economists dispute the applicability of Titmuss's finding in the context of caring labor. They contend that professional caring labor is not solely synonymous with other-regarding (or externalities) in the form of altruistic motivation to the point of self-sacrifice - as in a Mother Theresa type syndrome. Care work frequently requires specific skills and knowledge. Such knowledge may only be acquired through repeated interaction with the recipients of care, such as patients and children (Bergmann, 1986; Folbre and Nelson, 2000; Nelson, 2011). Far from crowding-out intrinsic motivation, improving wage levels in care sectors acknowledges care workers' contributions, and may therefore reinforce intrinsic motivation and improve the quality of care by, for example, reducing staff turnover (Nelson, 2006). This segues to the implications of the importance of the relational dimension in caring labor. Himmelweit (2007: 585), for instance, persuasively expresses an important implication of this:

"Caring because it is the development of a relationship, is manifestly an activity ... in which the output is the care itself ... This means that it is hard to raise the productivity of caring".

In articulating this, Himmelweit draws on Baumol and Bowen's (1965) analysis of the economics of the arts. The authors argue that productivity rises more quickly in areas of the economy that benefit directly from innovation, investment and/or technological enhancements. However, the arts cannot benefit from these effects. Baumol and Bowen use the example of a string quartet - reducing the number of players or demanding the musicians play more quickly may raise productivity in terms of the number of pieces performed per musician over a given time period, but would substantially alter the nature of the piece. The problem arises from the attempted objectification of the arts. The same can be said about the nature of care.

The second theme (wage disparities between the sexes) follows. Under the standard economic rubric, in competitive markets, wage levels reflect productivity. Feminists contend that professional care occupations are predominantly staffed by women, and such work is undervalued. This generates an obvious wage disparity between the sexes. In a noted contribution to the literature, Folbre (1995) counters what she terms as "supply-side arguments" advocated by the likes of Gary Becker and Victor Fuchs. In short, Fuchs (1988) argues that females derive greater utility from children than males, and therefore compensating differentials suggest that female wages will be lower than males' as women spend comparatively less time in the labor market. This is entirely rational and voluntary. For Folbre this ignores the "demand-side", which she describes in terms of collective action that results in discrimination. Part of this argument relates to male collusion that excludes women from highly-paid occupations, which crowds them into low-paid jobs. As the supply of women increases for such roles, the wage rate is bid down.

In sum, feminist economics acknowledges the three central dimensions of care (labor, philosophical, and psychological) identified in the care literature in the context of the economy as the theatre of social provisioning. As we understand it, feminist economics privileges the first of Power's (2004) components (caring and unpaid labor) in its analytical approach. We believe that this represents a development of thinking informed by viewing the economy as a provisioning process. We turn to tracing this out in sections 3 and 4 , returning to reflecting on how feminist economics arguably addresses the lacuna of care in contemporary economics in section 6 .

\section{Care in pre-neoclassical economic thought}


As noted in section 2, Power (2004) explicitly situates social provisioning as a Classical concept. Boulding (1986), for instance, attributes a notion of provisioning to Smith in which the study of the economy concerns how society is organized on the basis of exchange, and how society is provisioned. For Boulding, the second aspect incorporates the biosphere. In an economy, provisioning commenced with the production of food, and therefore was prominent in Classical analysis differentiated from commodities. The notion of social provisioning, we feel informed thinking on care. In this section we discuss the contributions of Adam Smith, Karl Marx and Thorstein Veblen on care. For us, Smith's work, in particular anticipates the feminist allusion to the relational aspect of caring.

\subsection{Adam Smith and care}

For most economists, the formative contribution to economics is Smith's Wealth of Nations in 1776. The Wealth of Nations $(W N)$ is frequently portrayed as establishing the basis for homo economicus and the motivation of utility maximization (for example, Becker, 1976). Moreover, Smith's references to self-interest as the "energy source" that drive the "gears" of the economy (for example, Nelson, 2006). The mechanistic metaphor crowds out feminine factors and combined with Smith's invisible hand metaphor provides a seemingly-powerful pro-market message: the way markets work seems to ensure that the pursuit of self-interest will benefit all. This is the vision promoted by the Chicago School.

Undoubtedly, Smith's butcher-baker tale diminishes beneficence and benevolence in generating material wellbeing. Yet to presume that this is all Smith said on the subject would be to commit a grave error of omission (Garnett, 2019; Terjesen, 2011). As Jerry Evensky (2005) argues, there are critical differences between the "Chicago Smith" and the "Kirkaldy Smith" (sic) ${ }^{3}$. The Chicago School representation of Smith is highly reductionist in that it ignores Smith's moral philosophy as set out in TMS (Evensky, 2005; Samuels, 1977; Samuels and Medema, 2005; Terjesen, 2011). For Evensky (2005: 203):

"Adam Smith was not an economist offering a materialist vision of humankind's progress based on the homo economicus assumption. Smith was a moral philosopher modeling a complex coevolution of individuals within a simultaneous system of social, political, and economic institutions."

There is also reason to believe that Smith was concerned with strengthening the arguments of TMS, which he worked on revising shortly before his death (Terjesen, 2011). He did not devote this much attention to revising WN (Montes, 2003). There are also those who emphasize the disjuncture between the apparent promotion of self-interest in $W N$ and $T M S$, as well as the inconsistencies within the $W N$ itself (for example, Foley, 2006). We acknowledge the debate and controversy over the two works (Garnett, 2019), but we are more interested in what Smith stated explicitly about care in TMS, the expression of Smith's ethical thinking (Samuels, 1977) .

At several points in TMS, then, Smith appears to anticipate later contributions to the theorizing of care. For example, in his insightful analysis, Andrew Tejersen (2011) demonstrates that Smith's use of sympathy refers to "fellow feeling", and hence emphasizes connectiveness and

3 Evensky's article misspells Smith's birthplace. "Kirkaldy" is not "Kirkcaldy". As far as we are aware, there is no "Kirkaldy" in Fife, Scotland. There is, however, a "Kirkcaldy".

4 Samuels identifies four domains to Smith's approach to moral philosophy: natural theology; ethics; justice, and concern for wealth (expediency). TMS explored ethics, and WN plutology. 
relatedness between individuals. In other words, individuals are not the atomistic entities of much of modern mainstream economics, but are socially situated. Sympathy is pivotal to Smith's analysis in TMS. It also highlights that for Smith, morality is inseparable from human actions, including economic activities (Ballet, et al, 2018; Evensky, 2005; Garnett, 2019).

In TMS, Smith contrasts beneficence and justice. He observes that the former demands gratitude whereas the latter does not. He notes that justice can be applied forcefully, whereas beneficence is "free" and cannot be "extorted by force" (Smith, 2000 [1759]: 112). Further, he associates beneficence with generosity, and how this requires an acknowledgement on the part of the beneficiary of acts of beneficence. He argues that there is never a debt of charity, generosity, or friendship, but there is a "debt of gratitude." Smith develops his theme further when he argues (2000 [1759]: 117):

"Beneficence and generosity we think due to the generous and beneficent. Those whose hearts never open to the feelings of humanity, should, we think, be shut out in the same manner, from the affections of all their fellow-creatures, and be allowed to live in the midst of society, as in a great desert, where there is nobody to care for them, or to enquire after them" (emphasis added).

Interestingly, Smith argues that beneficence is virtuous, and that there is an obligation on us to recognize it as such. If an individual does not acknowledge beneficence (or benevolence), then there is no obligation for the benefactor to continue to provide for the beneficiary. The passage above reinforces Smith's affinity to other-regarding features of human behavior (and obligations to do so), and hence, in our view, emphasizes the social embeddness of the individual. Smith's invocation of "care for" also appears to anticipate the complexities of care as relational, embodied in acts and emotions - primarily affection - as captured to some degree by his notion of sympathy, and invoking benevolence and beneficence. He further explores this in later parts of TMS on the foundation of judgments relating to individual conduct, sentiments, and a sense of duty (Part 3), and in Part 5, Section 2 on the otherregarding properties of virtuousness. Indeed, Smith makes explicit reference to care in the title of Chapter 1 of Section 2.

In discussing "just and unjust" conduct, Smith refers to the notion of "general rules" as providing the foundations for standards of judgment. In terms redolent of Thorstein Veblen, Smith argues that general rules are "fixed in our mind" by "habitual reflection" (2000 [1759]: 226). Moreover, these rules constrain individuals' pursuit of self-interest at the expense of regard for others. In our view, however, Smith appears to go further than arguing that social rule systems are only constraints, since he uses a particular terminology, "correcting the misrepresentations of self-love." Further, Smith's use of "habitual" and reference to "fixed in our mind" suggest that rules instill values in our thought that are deemed culturally acceptable (see also, Garnett, 2019). Thus, we believe Smith's framing is consistent with the argument that caring, as a virtue, is partly shaped by the system of rules governing social conduct and relations.

We venture further. When discussing virtue in Part 5, Smith represents care in terms of concentric rings. "Every man, as the Stoics used to say, is first and principally recommended to his own care" (2000 [1759]: 321). From the self, care as other-regarding extends to one's immediate family or kin - with greater sympathies directed at children - and then on to familiar others. Place and relationality play an important role in Smith's analysis here. His thinking here is informed by David Hume's preoccupation in his A Treatise of Human Behavior with the issue of distance on morality (for example, Dow, 2002; Dow and Dow, 2006). For Smith, distance does not make the heart grow fonder. This is due to the key role Smith ascribes to habit: "What is called affection is in reality nothing but habitual sympathy" (2000 [1759]: 323), and for this proximity is a key influence. 
Care, then, is bound up with affection, sympathy, and virtue. It is, as we have seen, also associated with beneficence and is deeply relational in Smith's schema. Yet Smith readily appreciates how the prevailing conditions of society may change general rules and therefore the conduct of relations between individuals. He also draws a distinction between "pastoral" and "commercial" countries, where the former do not possess legal frameworks sufficiently developed to ensure the "security of every member of the state" (2000 [1759]: 326). In pastoral societies different branches of a family and its associates coalesce to ensure their mutual "security." He suggests that in less developed societies deeper bonds exist between its members, certainly at a local level, and that there is likely to be greater affection, sympathy and care. With commercialization there is less need for such bonds, as the legal apparatus assumes this function (on other aspects of Smith's analysis of commercial societies, see Witztum, 2008). This invites the question as to whether economic progress, in Smith's approach means that we care less for each other. Nonetheless, regardless of the state of social development, Smith believes that mutuality and kindness are intrinsic to being human.

A sense of social provisioning is suggested from Smith's inference of a virtuous cycle: kindness generates kindness, and further, the well-being of individuals is founded on their sociality. Kindness renews and replenishes: exercising kindness does not exhaust some 'stock'. Indeed, Smith envisions a complex milieu in which socially connected individuals negotiate their daily affairs by reference to social rules, and where care, affection, and sympathy play a significant role in the conduct of their relations. Moreover, there is a certain obligation, if not responsibility - witness the sense of duty noted earlier - in being otherregarding in Smith's thinking. We return to this in section 6. Yet, while Smith explicitly refers to care, he offers no precise definition. It seems evident that his understanding of care related primarily the psychological dimension identified earlier, in that caring is fundamentally emotional. His analysis entangles care with what he describes as virtuous properties of human behavior: kindness, sympathy, beneficence, attention, affection, and so forth. It appears that Smith was aware of the complex nature of care and caring - witness his references to "nature" and kindness, the emphasis he placed on proximity and relations, and the role of habit (and hence learning) in framing care. Yet as Tejersen (2011) recognizes, Smith unfortunately introduced a gender bias in his account. Smith's notion of "self-command" over emotions was a decidedly masculine attribute. If care is viewed as possessing an emotional element, then it becomes distinctly feminine, and therefore subject to marginalization. Therein lies an unfortunate consequence. By invoking a gendered understanding of care, Smith perhaps unintentionally sows-the-seeds of care's shift to the periphery of economic thinking.

\subsection{Karl Marx}

Marx shared with Smith an Aristotelian perspective, and from this develops a markedly humanist orientation in his theoretical approach. Marx's understanding of capitalist market exchange addresses the conflict between market-based interactions and social conditions that would facilitate care. Specifically, in Chapter 1 of Volume 1 of Capital, in what he terms the "fetishism" of the commodity, Marx argues that exchange value always dominates use value. Indeed, he speculates that if commodities could speak they would say: "We relate to each other merely as exchange-values" (Marx, 1990 [1867]: 177). In other words, the value of all things comes to be measured by prices - a monetary measure of the value for which a 'thing' can be exchanged. This monetization of things contaminates and corrupts other values in social relations, and collectivism and co-operation give way to individualism and exploitation. Thus, the prospect for care and caring beyond the self, and other-regarding attitudes and behaviors, is seriously diminished. 
A manifestation of this that preoccupied Marx is the length of the working day. The exploitative nature of production relations always acts to lengthen the working day and limit the time workers have to attend to their social and other needs, and is accordingly dehumanizing.

Nonetheless, the concept of care is not directly evident in Marx's analysis, and his thoughts about it can only be inferred from other things he says. To our knowledge, where Marx does employ the term "care" its meaning is either as a burden (as all the cares of the World) or as an exercise of diligence, such as, "the capitalist takes good care that the work is done in a proper manner" (1990 [1867]: 291). This treatment of care is not surprising given the pivotal role of conflict in Marx's analysis. Yet, given his humanist orientation indicates that there can be no moral equivalence between people and machines. Moreover, Marx's emphasis on value theory and his critique of the monetization of social relations, provide a platform for the circumstances of care and caring. Indeed, the Marxist emphasis on production relations and the reproduction of those relations is the basis of a definition of care, and conceptualizing care as central to human existence (for example, Davis and McMaster, 2017; Folbre, 1995; Schwarzenbach, 1996). Moreover, Marx's historical and material dialecticalism powerfully signals a change in dominant value structures underpinning production and wider social relations. It is therefore not inconceivable that, for example, Marx's conception of "primitive communism" points to a more caring society in that it is typified by sharing and co-operation than the materially wealthier "capitalism" at the focus of his writing. Indeed, this echoes Smith's allusion to the effects of commercialization, noted earlier Marx's vision of a communist society that eventually succeeds capitalism appeals to a more caring sense of social relations. Tronto (1993), for example, notes that Marx's analysis proposes that under capitalism, frequently the individual (proletarian) cannot see much beyond their own plight in order to be other-regarding; so that capitalist relations are almost necessarily around care-for-the-self. However, when an individual's own needs are sufficiently met they become increasingly sensitive to the needs of others. Here the potential for the relational aspect of care and caring is reiterated.

\subsection{Thorstein Veblen and the "parental bent"}

The final figure we highlight is Thorstein Veblen. While Veblen's approach resonates with social provisioning, it is less obvious which of Power's components he emphasizes. Veblen obviously articulates the economy as subject to evolutionary forces and furnishes a fuller psychology of human behavior. He explored this in his The Instinct of Workmanship and the State of the Industrial Arts (TIW) published in 1914.

Veblen's theoretical analysis of human behavior was heavily influenced by American instincthabit psychology (Hodgson, 2004). He believed that human instincts are part of our evolutionary biology in the form of innate and persistent propensities and drives (for example, Camic and Hodgson, 2011; Kologlugil, 2016). He identified three basic instincts, including; "workmanship", which is an impulse to work to make things useful; "idle curiosity", which refers to humans' drive to comprehend the external world, perhaps through imagination; and the "parental bent" (Veblen, 2011). The parental bent is explicitly other-regarding and far broader than the, "mere proclivity to the achievement of children" (Veblen, 2000 [1914]: 16). It is:

"Beyond question that this instinctive disposition has a large part in the sentimental concern entertained by nearly all persons for the life and comfort of the community at large, and particularly for the community's future welfare" (Veblen, 2000 [1914]: 17).

Veblen depicts the parental bent as a "naïve impulse" (Ibid.) that is manifest in two ways: an active interest in common good, and hence other-regarding, and a bias to the future. $\mathrm{He}$ contends that there is an "unselfish solicitude" (2011: 561) expressed as a concern for the 
"highest efficiency" (Ibid.) to ensure the well-being of the in-coming generation. In other words, current generations make sacrifices to enhance the life chances of the young.

Despite identifying the parental bent as one of the two most important human instincts - the other being workmanship - Veblen devotes remarkably little text to exploring and elaborating upon it. As the title of his work indicates, the principal focus is workmanship. That said, he does consider how the two instincts may relate to one another in guiding behavioral impulses. Instincts are translated via habits into behavior, and through habits instincts may become corrupted. Veblen illustrates the parental bent in the context of paternalistic authoritarian rule by elders in some tribal societies, and how the perpetuation of particular habits leads to an institutional pattern that demarcates clear class distinctions. Other than this, Veblen does not develop the parental bent concept, or explicitly relate it to the terminology of care. Nevertheless, for us it is clear that Veblen's conceptualization strongly resonates with notions of care and caring. The instinctive property is an obvious corollary. Within this, Veblen's delineation of care is expressed by other-regarding, concern or interest, and a future orientation. Again, these constitute aspects of care and caring, and seems to engage with the psychological dimension through emotional disposition. Moreover, Veblen's emphasis on the future is consistent with Fisher and Tronto's (1990) definition and suggests a sentiment promoting the sustainability aspect to care perhaps not evident in Smith. What remains unexplored in Veblen's analysis, yet constitutes an important part of Smith's approach, is the idea of care as a virtue. This may be unsurprising given the respective orientations of Smith's TMS and Veblen's TIW, and perhaps this deserves some reflection on the possibilities of synergies between Smith and Veblen's analyses of care. Nonetheless, in the relevant parts of TIW Veblen makes no reference to Smith.

Of the three figures identified, Smith provides the most thorough examination of care, and yet his thinking is under-elaborated and potentially gender-biased. Veblen's allusions are indirect and under-developed, whilst Marx provides only a hint of the conditions involved in caring, which can be inferred from his excoriating critique of the corrupting effect of the monetization of social relations. Given that care was not the primary focus of these authors there is only a disjointed, fragmented approach to care. For instance, Marx's Aristotelian roots and humanism are suggestive of an emphasis on care, but one has to read between the lines to discern this. In the case of Veblen, the parental bent is presented as one of the two most important human instincts; nevertheless, as noted, it is subsequently under elaborated in his work. Neither Marx nor Veblen establish any overt references to responsibility in providing care, whereas Smith infers some obligation. Yet to varying degrees, all three anticipated later developments in theories of care. We turn to Kenneth Boulding's systems approach to the social provisioning economy.

\section{Kenneth Boulding: Recapturing early Classical promise?}

As an economist Kenneth Boulding is perhaps best known for his interdisciplinary approach to the analysis of the economy, which reflected his systems-based and evolutionary analyses (Dolfsma and Kesting, 2013), and his strong belief that all sciences are infused with values, economics being no exception (Boulding, 1969; Davis, 2013).

Boulding's system-based approach appeals to social provisioning. Indeed, Boulding (1986) chastises "neoclassical" economics in failing to appreciate this Classical insight. He states: 
"Modern economics has gone wholly towards the view of economic life as society organized by exchange, and has largely lost sense of it being a process of provisioning of the human race, or even the whole biosphere" (1986: 10). ${ }^{5}$

Boulding endorses ("his beloved") Adam Smith's notion of the provisioning of society. For Boulding, it highlights a hierarchy of entities necessary to fulfil species functioning and (social) reproduction. Under standard economics, according to Boulding each commodity assumes equality in a society organized solely on the basis of exchange. Arguably, this entails the conflation of needs and wants, and assumes individual autonomy. By contrast, understanding of the economy as a process of social provisioning suggests a differentiation between needs and wants and human interdependency.

Boulding's second point, above on the nesting of science in values has some bearing on our argument. Boulding is forthright in asserting that science is a human activity that occurs within a community, and all communities and human activities are types of culture that provide ethical guidance regarding what is right and wrong. Therefore, science cannot be divorced from morality. In his 1968 American Economics Association address, Boulding denounces the ethical foundations of Pareto optimality, arguing that it precludes malevolence and benevolence from socio-economic activities (Boulding, 1969).

Benevolence, of course, is what Smith in TMS connected with care and other-regarding. By this argument, then, almost at the outset of its analysis the mainstream marginalizes care. Boulding's $(1969 ; 1973)$ assessment is predicated on his three systems of social organization conception, the "threat", "exchange", and "integrative" systems. In the threat system the dominant motive is fear; in contrast the integrative system is dominated by love. The systems overlap and evolve. Boulding argues that the integrative system sustains the exchange system: benevolence gives rise to reciprocity, a pre-requisite for exchange (Boulding, 1973). However, he also notes that the exchange system is partially shaped by the threat system, which is also influenced by the integrative system. The threat system is the basis of power politics, as exchange is the basis of economics. In his many works on this he describes the multitude manifestations of the threat system, frequently summoned by the State. Thus, Boulding refers to an evolution of spiritual threats, legally sanctioned coercion, physical threat, slavery, and so forth throughout human history.

Love centers on other-regarding through identification. Boulding argues that there are areas of life that do not involve exchanges or threats, but in which we identify with others. $\mathrm{He} \mathrm{(1973)}$ describes love of spouse, family, country and so on as part of our identity. Boulding further argues that the three systems depend on learning. Without learning benevolence would not lead to reciprocity; without learning we would not appreciate the nature of subtlety in the threat system and threats would be reduced to the coarse exercise of physical power. Through learning, Boulding reinforces his case that all sciences are morally based. He demonstrates this with even greater specificity in his study of need and health care.

Drawing from the overarching notion of provisioning, Boulding commences his argument from the proposition that needs and wants are profoundly different. As in market exchange systems, demand represents individual choice and autonomy whereas need refers to the choices of others made on one's behalf, inferring an absence of autonomy and the presence of dependency. For Boulding this may be related to what he terms as "homeostatic need", which is what is required to maintain the operability (or functionality) of a given system. To demonstrate the ethical challenges of this, Boulding draws a comparison between cars and

\footnotetext{
${ }^{5}$ We are grateful to an anonymous reviewer for bringing Boulding's view on this to our attention.
} 
humans - both need fuel of various types, produce waste, are subject to physical deterioration, and frequently requires specialist professionals for the purposes of maintenance. He argues that basing need on homeostasis is never successful, as no matter what the nature and combination of inputs, "virtually all known organisms and organizations exhibit the phenomenon of aging ... Aging introduces a very tricky problem into the concept of need for maintenance" (Boulding, 1966: 206-7). When is it appropriate to cease maintaining something? Boulding argues that this is problematic enough with a machine, where present value calculations can be used, but one of "excruciating delicacy" (1966: 207) in the case of a human being. He observes (Ibid.):

"A machine is generally regarded as having no value in itself ... its value is purely instrumental ... In the case of the human being, the problem of the person himself becomes very acute, because persons cannot be regarded as purely instrumental. That is, they are not merely good for something else, they are good in themselves. They are, in other words, something for which other things are good" (original emphasis).

Boulding's privileging of humans has an obvious affinity with the tenor of an ethics of care, and moreover appears intuitively appealing from Aristotelian and Kantian perspectives, and sharing a lineage with Smith, Marx, and Veblen. Nonetheless, for us, there is a lacuna in Boulding's stimulating analysis: there is no explicit mention or reference to care. Care and caring may be inferred from his emphasis on professional values and his situating medical provision in the integrative system with its dominant value of benevolence, but surprisingly Boulding makes no particular virtue of caring. The central characteristic of the integrative system, the bonding effect of love via identity, is similar to the familiarity and care argument articulated by Smith in TMS. Yet the absence of explicit reference to care and caring is disappointing. Boulding provides the platform, but seems to overlook its potential in examining care. For this, we must turn to feminist economics. For now, we focus on mainstream or standard economics and care.

\section{Mainstream economics and care: Never the twain shall meet?}

It seems reasonable to argue that care is not prominent in the mainstream economic literature. Leaving aside this seeming incongruity with the universality of care and caring in human behavior, this section outlines the approaches to care in the mainstream literature. We do not endeavor to be comprehensive here, again merely illustrative. We note that branches of the mainstream, such as family economics (for example, Becker, 1981; Bergstorm, 1996) refer to "care" as a source of utility and in the context of repeated games. Nonetheless, we demonstrate our argument through health economics, which, like family and labor economics employs standard techniques. Our principal reason being that we are most familiar with health economics.

In her insightful contrastive analysis of the economic modelling of care, Irene van Staveren (2005) observes that the standard approach treats care in different ways. Some models include "care" as a time allocation decision variable in the supply of labor, usually between paid labor, unpaid labor, as proxy for care, and leisure. Care may also be modelled as a category of leisure. Such models endogenize care by assigning a price vector, such that care therefore assumes a monetized opportunity cost. Thus, as with any other standard commodity, care is a declining function of price. Its responsiveness to price changes may then be modelled as a means of investigating gender labor market issues, such as wagegaps. If the division of care in a household is mainly assumed by women, which is translated into a household preference function, then the opportunity costs of care will differ between the genders. There is no acknowledgement of the meanings or values of caring relationships. 
For van Staveren (2005: 582), such models can only provide insight into what she terms as the "economic structure of care", i.e., time allocation decisions across a range of activities.

We argue that standard health economics is no different from the rest of the mainstream in its treatment of care as a marginal issue. However, where care does feature in standard analyses, either explicitly or by implication, it is treated in two overlapping ways: as altruism and/or social capital. In effect, care is modelled as interdependent utility functions between at least two economic agents: it is an externality. Indeed, some health economists are explicit about this. For example, Culyer (1976) refers to "humanitarian spillovers" between the wider population and those who are ill. Bobanic, et al, (2010) describe care interventions as "spillovers" on "significant others". For Mooney and Ryan (1993), a "caring externality" in an agent's utility function generates a benefit flow to this agent from the knowledge that other members of the population have the ability to access health care regardless of their ability to pay. Wiseman (1997) presents a refinement in associating process utility with care, arguing that utility may be derived from the act of caring or giving, as well as the consequences of care-giving. Drawing from Margolis' (1982) fair shares model, Wiseman contends that individuals possess two utility functions: one deriving from "selfish utility" and the other from group or social activities. The dual utility function approach is a heuristic device to account for how seemingly irrational acts, seen from a strictly selfish perspective - such as altruistic care giving at personal cost - can be explained as rational acts consistent with utility derived socially (Davis and McMaster, 2015).

Treating care as an externality makes it as an aspect of social capital, since most contributions to this approach define social capital in terms of non-rivalrous public goods (Folland, 2006) or overtly as an externality (Portes, 1998). Indeed, the social capital literature supposes that caring social relationships have powerful beneficial effects (for example, Dahl and MalmbergHeimonen, 2010).

Yet the standard economic conceptualization of care, in general, and in health economics, in particular is subject to profound logical problems.

For example, the notion of a 'caring externality' is problematic in that the spillover is not on a third-party, as in the usual understanding of an externality, but to one of the parties in the caring relation. Modelling care via interdependent utility functions (for example, Wiseman, 1997) suggests that the care provided is additional to the activities delivered. Specifically, medical treatment is delivered to a patient whether or not the clinician is particularly caring. This is problematic, since on the standard view, caring defined as an externality limits it to a secondary, non-essential type of factor since a commodity is provided regardless of the supplier's caring preferences. If care is an externality, it is then by definition a second-order concern to the pursuit of individual utility. Where the two conflict, there is a tendency for care to be crowded out. Ethical motives are always at risk when economic ones dominate (Davis and McMaster, 2015; 2017). Indeed, Ballet, et al (2018) in citing Mahieu (2001) observes that by treating concern for others as an externality introduces a moral equivalency in choosing between the consumption of a particular cheese and assisting one's grandmother.

Regard for others features prominently in the so-called behavioral turn in mainstream economics (for example, Davis, 2008; Hargreaves Heap, 2013). Moreover, emotions, such as guilt and envy have been incorporated into mainstream models (Ballet, et al, 2018). Yet such initiatives tend to theoretically proceed from the examination of anomalies to the standard rational choice model (Hargreaves Heap, 2013), and therefore do not represent an abandonment of, but an amendment to homo economicus. Indeed, Shaun Hargreaves Heap argues that the new behavioralism in economics appeals to the mainstream in part due to its methodological frame, which centers on 'as if' reasoning. 
Arguably, incorporating emotions into a utility function is reductionist in that an emotion is confined to the properties of any other argument in a utility function; namely, a single measurable dimension. In effect, by theorizing care as other regarding in terms of interdependent utility functions, the standard approach conflates care with its interpretation of altruism, sympathy, and emotions, more generally.

Elias Khalil (2003) provides an insightful analysis of the examination of altruism. He distinguishes three approaches: 'egoistic', where altruism revolves around the expectation of the accrual of future benefits to the altruist; 'egocentric', where there is an interdependency of utilities, and 'altercentric', which, for Khalil refers to a particular personality trait, where, for instance, an individual is pre-disposed - regardless of (monetary) incentives - to be otherregarding. Thus, an altercentric individual may be inclined to behave altruistically by virtue of their ability to demonstrate concern for another where this concern is not self-centered.

Mainstream theorizing presents only a specific form of care and altruism, and one that fails to acknowledge social context. Limiting its analytical prospectus to the egoistical variant means that the standard account rests entirely on an individualistic basis in that it does not appeal to a moral obligation associated with a particular social role (Davis and McMaster, 2017). Therefore, in our view, this gives altruism, and hence care an ephemeral quality, which is sensitive to the whims of a particular individual and is not necessarily socially embedded in a sense of duty or responsibility.

\section{A return to feminist economics: Addressing mainstream neglect?}

Our understanding of care in economics to some extent rests on viewing the economy as a process of social provisioning in the sense expressed by Marilyn Power (2004). Such a lens is evident in pre-neoclassical thinking. Arguably, Smith provides the antecedents for the conceptualization of care in economic behavior. Veblen enriches this through his habit-instinct psychological perspective but fails to sufficiently develop care beyond its instinctive property. Boulding's systems analysis augments Smith's association of care with a particular set of values, such as sympathy. Unfortunately, to the best of our knowledge, beyond some isolated favorable citations of Smith (for example, Bergstorm, 1996), mainstream economics does not, and perhaps cannot retain the notion of social provisioning, which is arguably necessary but insufficient for an appreciation of care. As we understand it, the standard economic approach to care is reductionist in that it is highly sensitive to an individual agent's preferences, and therefore is solely the subject of an optimizing decision rubric with the moral equivalent of commodity choice. In contemporary economics, it is left primarily to feminist economics to address this neglect.

We emphasize two cases where feminist economics is deepening the understanding of care in the economy. The first centers on the philosophical dimension, specifically responsibility. The second, outlines some recent work on care regimes and economic growth.

The standard economic rationalization of the disproportionate distribution of caring labor activities on females, as we noted, rests on preferences, such as women having greater predisposition to childcare (for example, Fuchs, 1988). Such arguments ignore the philosophical, specifically ethical aspect of care. The broader care literature examines how much dependencies are associated with the assumption of responsibility for care provision, inter alia (for example, Engster, 2005; Tronto, 1993, 2013). Unlike the egocentric altruistic explanation of the mainstream, which makes no reference to social roles, the notion of responsibility refers to a set of moral obligations potentially nested in an individual's social roles, for example by virtue of parenthood or a particular occupation. These responsibilities emerge regardless of the individual's preferences, at least in the conventional economic sense. Feminist economics 
has recognized the heavily gendered aspect to caring responsibilities (for example, Folbre, 1986; Himmelweit, 1995).

Recently, Nelson (2016) has attempted to promote a masculine-oriented ethic and practice of care through the invocation of the "masculine term, "husbandry". In its traditional meaning, husbandry is associated with "careful cultivation" and "management" (Nelson, 2016). In other words, it is is evocative of ethical properties of attentiveness and responsibility in productive activities. This, she argues markedly contrasts with the "robotic profit-maximizer ... or industrial worker, financialized masculinity" (Nelson, 2016: 5, original emphasis) of standard economic accounts of behavior founded on homo economicus. Husbandry requires skill and creativity, as well as care, suggesting that the latter is by no means an exclusively feminine preserve. In a powerful conclusion, Nelson (2016: 12) writes:

"Caring is a human trait, and care is a human responsibility, in all areas of life in which we find ourselves. Men who neglect their capability to care are less fully men. An economy that neglects care advances toward only greed, robotic work and ecological destruction" (emphasis added).

Although feminist economics transcends methodological boundaries, with the employment of mainstream techniques in the investigation of caring labor, in particular, it nevertheless challenges the adequacy of standard practice, especially the value-ladeness of homo economicus (for example, Nelson, 2003). Nelson (2016) appeals for a reconsideration of one of the tenets of the standard approach. Homo economicus is the unthinking, robotic pursuit of utility maximization. According to Nelson's argumentation it is thus dehumanizing, and therefore incongruous with an adequate conception of care.

Going beyond the ethical attributes of care, feminist economists also investigate care in terms of social reproduction. Elissa Braunstein and colleagues' work (for instance, Braunstein, et al, 2018) on social reproduction and economic growth provides an illustrative example. Braunstein, et al attempt to incorporate care into a Kaleckian based model. Again, gender features prominently as they acknowledge care as an output and an aspect of labor-process, disproportionately provided by women. The authors model care in echoes of Keynes' "animal spirits" in what they term as "caring spirits". This is described as investments in human capacities that reflect social norms and individual motivations to care. They claim this is reflected in the structure of the social welfare state. There is an affinity with a varieties of capitalism type analysis in that Braunstein, et al are then able to present categorical measures for the purposes of modelling. Moreover, it potentially develops a theory of care from a (Post) Keynesian perspective, which to all intents and purposes has been largely absent (McMaster, 2018).

Care, then is clearly a central concern for feminist economics, and arguably its adoption and development of the notion of social provisioning associated with Classical political economy facilitates elaboration. The narrower foundation of mainstream economics suggests that it can only present a rather superficial account of care in the economy.

\section{Conclusions}

We believe that charting the history of care in economic thought is important as it serves at least two purposes: first, that prominent figures in a more political economy tradition at least acknowledged care as a feature of economic life. Second, with the emergence of what is now mainstream economics, care was (and is) marginalized in the conceptualization of human behavior. Those areas of standard economics that attempt to model care, such as family and health economics, reduce it to an argument in an interdependent utility function. In doing so, 
care has the moral equivalence of any commodity. This may render modelling easier in tracing utility maximizing individuals' choice sets but generates questionable ethical issues. Is care really equivalent to a commodity?

The systems approach of Kenneth Boulding provides an insightful means of challenging the moral equivalence of care and commodities in the standard approach. Boulding's thinking questions the basis of treating care as an externality and demonstrates the reductionist tenor of the mainstream. Under Boulding's schema, the standard approach is confined to the exchange system, and care would be located in the integrative. While these two systems are not entirely discrete, there remains the issue as to whether care can be adequately understood by an approach solely nested in the exchange system. Yet, whilst Boulding's analysis is promising from the perspective of furnishing a deeper understanding of care, it is frustratingly under-developed in that, at least to the best of our knowledge, Boulding makes no explicit reference to care.

It is left to feminist economics to develop a richer understanding of the importance of care. Here there is no avoidance of the complexities of care, nor its ethical underpinnings. The origins of the care concept in feminist social science, economics, and philosophy lie in recognition of social provisioning and within this the importance of unpaid labor in non-market domains. Feminist economics, in our view resuscitates and augments the insights of the political economy conception of social provisioning, such as power structure and ethical framing in an evolutionary dynamic. More specifically, this analysis acknowledges the relational aspect of care and caring. Having a caring attitude, involves not just an orientation on the part of the caregiver, but also a personal engagement with the overall well-being of the recipient of care. This thinking recalls Smith's early view of care as bound up with affection, sympathy, and virtue. The feminist agenda on care is challenging, then, in that its implications confront the conventional rubric of economic organization predicated on self-interest. What if homo economicus was usurped by homines curans (Tronto, 2017)?

\section{References}

Ballet, J., Petit, E., and Pouchain, D. (2018) What mainstream economics should learn from the ethics of care, CEconomia, 8: 187-208.

Baumol, W. G. and Bowen, W. G. (1965) On the performing arts: the anatomy of their economic problems, American Economic Review, 50: 495-502.

Becker, G. A. (1976) The Economic Approach to Human Behavior, Chicago: University of Chicago Press.

Becker, G. A. (1981) A Treatise on the Family, Harvard University Press: Cambridge MA.

Bergmann, B. (1986) The Economic Emergence of Women, New York: Basic Books.

Bergstorm, T. C. (1996) Economics in a family way, Journal of Economic Literature, 34: 19031934.

Boulding, K. E. (1966) The concept of need in health services, Milbank Memorial Fund Quarterly, 44: 202-223.

Boulding, K. E. (1969) Economics as a moral science, American Economic Review, 59: 1-12. 
Boulding, K. E. (1973) The Economy of Love and Fear: A Preface to Grants Economics, Belmont, CA: Wadsworth Publishing Company.

Boulding, K. E. (1986) What went wrong with economics? The American Economist, 30: 5-12.

Braunstein, E., Seguino, S., and Bouhia, R. (2018) Social reproduction, gender equality and economic growth, paper presented at the Association for Social Economics, World Congress, June.

Camic, C. and Hodgson, G. M. (eds) (2011) Essential Writings of Thorstein Veblen, London: Routledge.

Davis, J. B. (2008) The turn in recent economics and return of orthodoxy, Cambridge Journal of Economics, 32: 349-366.

Davis, J. B. and McMaster, R. (2015) Situating care in mainstream health economics: An ethical dilemma? Journal of Institutional Economics, 11: 749-767

Davis, J. B. and McMaster, R. (2017) Health Care Economics, Routledge: London and New York.

Dow, S. C. (2002) Historical reference: Hume and critical realism, Cambridge Journal of Economics, 26: 683-695.

Dow, A. and Dow, S. C. (eds) (2006) A History of Scottish Economic Thought, Routledge: London.

Edwards, S. D. (2009) Three versions of an ethics of care, Nursing Philosophy, 10: 231-240.

England, P., Budig, M. and Folbre, N. (2002) Wages of virtue: The relative pay of care work, Social Problems 49 (4): 455-73.

Engster, D. (2005) Rethinking care theory: The practice of caring and the obligation to care, Hypatia, 20: 50-74.

Evensky, J. (2005) Chicago Smith versus Kirkaldy (sic) Smith, History of Political Economy, 37: 197-203.

Folbre, N. (1986) Of hearts and spades: Paradigms of household economics, World Development, 14: 245-255.

Folbre, N. (1995) 'Holding hands at midnight': The paradox of caring labor, Feminist Economics, 1: 73-92.

Folbre, N. and Nelson, J. A. (2000) For love or money - Or both? Journal of Economic Perspectives, 14: 123-140.

Folland, S. (2006) Value of life and behavior toward health risks: An interpretation of social capital, Health Economics, 15: 159-171.

Fuchs, V. (1988) Women's Quest for Economic Equality, Harvard University Press: Cambridge. 
Garnett, R. (2019) Smith after Samuelson: Care and harm in a socially entangled world, Forum for Social Economics, 48: 125-136.

Gilligan, C. (1982) In a Different Voice: Psychological Theory and Women's Development, Harvard University Press: Cambridge, MA.

Hargreaves Heap, S. P. (2013) What is the meaning of behavioural economics? Cambridge Journal of Economics, 37: 985-1000.

Held, V. (2006) The Ethics of Care: Personal, Political, and Global, Oxford University Press: Oxford.

Himmelweit, S. (1995) The Discovery of 'unpaid work': The social consequences of the expansion of 'work', Feminist Economics 1: 1-19.

Himmelweit, S. (2007) The prospects for caring: Economic theory and policy analysis, Cambridge Journal of Economics, 31: 581-599.

Ironmonger, D. (1996) Counting outputs, capital inputs and caring labor: Estimating gross household product, Feminist Economics, 2: 37-64.

Khalil, E. (2003) What is altruism? Journal of Economic Psychology 25: 97-123.

Kologlugil, S. (2016) Thorstein Veblen's Darwinian framework and gene-culture coevolution theory, European Journal of the History of Economic Thought, 23: 641-672.

Mahieu, F. (2001) Ethique Économique: Fondements Anthropologiques. Paris: L'Harmattan.

Margolis, H. (1982) Selfishness, Altruism and Rationality, Cambridge: Cambridge University Press.

Marx, K. (1990 [1867]) Capital, Volume 1, London: Penguin.

McMaster, R. (2018) Does Post-Keynesianism need a theory of care? in Money, Method, and Contemporary Post Keynesian Economics, Dow, S. C., Jespersen, J., and Tily, G. (eds), Cheltenham: Edward Elgar..

Montes, L. (2003) Das Adam Smith problem: Its origins, the stages of the current debate, and one implication for our understanding of sympathy, Journal of the History of Economic Thought, 25: 63-90.

Mooney G. and Ryan M. (1993) Agency in health care: getting beyond first principles. Journal of Health Economics, 12: 125-135.

Nelson, J. A. (2003) Confronting the science/value split: Notes on feminist economics, institutionalism, pragmatism and process thought, Cambridge Journal of Economics, 27: 4964.

Nelson, J. A. (2006) Economics for Humans, Chicago: Chicago University Press.

Nelson, J. A. (2011) For love or money? Current issues in the economics of care, Journal of Gender Studies

(Ochanomizu University): 1-19, http://www.igs.ocha.ac.jp/igs/IGS publication/journal/14/120.pdf 
Nelson, J. A. (2013) Gender and caring, in Handbook of research on gender and economic life, D. Figart and T. Warnecke, eds., Cheltenham: Edward Elgar Publishing.

Nelson, J. A. (2016) Husbandry: A (feminist) reclamation of masculine responsibility for care, Cambridge Journal of Economics, 40: 1-15.

Noddings, N. (1984) Caring, University of California Press: Berkley.

Portes, A. (1998) Social capital: Its origins and applications in modern sociology, Annual Review of Sociology, 24: 1-24.

Power, M. (2004) Social provisioning as a starting point for feminist economics, Feminist Economics, 10: 3-19.

Samuels, W. J. (1977) The political economy of Adam Smith, Ethics, 87: 189-207.

Schwarzenbach, S. (1996) On civic friendship, Ethics, 107: 97-128.

Smith, A. (2000 [1759]) The Theory of Moral Sentiments, Prometheus Books: Amherst MA.

Smith, A. (2000 [1776]) An Inquiry into the Nature and Causes of the Wealth of Nations, Penguin: London.

Terjesen, A. (2011) Adam Smith cared, so why can't modern economics? The foundations of care ethics in early economic theory, in Hamington, M. and Sander-Staudt, M. (eds), Applying Care Ethics to Business, Issues in Business Ethics (34), Springer: New York.

Titmus, R. (1971) The Gift Relationship: From Blood to Social Policy, George Allen and Unwin: London.

Tronto, J. C. (1993) Moral Boundaries: A Political Argument For an Ethic of Care, Routledge: London.

Tronto, J. C. (2013) Caring Democracy: Markets, Equality, and Justice, New York University Press: New York.

Tronto, J. (2017) There is an alternative: Homines curans and limits of neo-liberalism, International Journal of Care and Caring, 1: 27-43.

van Staveren, I. (2001) The Values of Economics: An Aristotelian Approach, Routledge: London.

van Staveren, I. (2005) Modelling care, Review of Social Economy, 63: 567-586.

Veblen, T. B. (2000 [1914]) The Instinct of Workmanship and the State of the Industrial Arts, Kessinger Publishing: Whitefish, MN.

Waerness, K. (1984) Caring as women's work in the welfare state, in H. Holter, ed., Patriarchy in a Welfare Society, Oslo: Universitetsforlaget: 67-87.

Wagman, B. and Folbre, N. (1996) Household services and economic growth in the U.S., 1870-1930, Feminist Economics 2: 43-66. 
Wiseman, V. (1997) Caring: The neglected health outcome? Or input? Health Policy, 9: 4353.

Witztum, A. (2008) Smith's theory of actions and the moral significance of unintended consequences, European Journal of the History of Economic Thought, 15: 401-432. 